\title{
Perencanaan Pembangunan Dan Gerakan Sosial Dalam Reforma Agraria Di Indonesia
}

\author{
Febrie Hastiyanto \\ Perencana Madya Bappeda dan Litbang Kabupaten Tegal
}

\begin{abstract}
Abstrak; Reforma Agraria telah menjadi satu isu gerakan sosial di Indonesia. Pada praktiknya karakteristik gerakan yang tumbuh untuk memperjuangkan Reforma Agraria memiliki varian yang beragam. Diferensiasi ini dipengaruhi oleh preferensi aktor gerakan dalam memaknai Reforma Agraria untuk kepentingan perjuangannya. Tak dapat dielakkan, gerakan Reforma Agraria-sebagaimana tipologi isu gerakan yang lain-adalah akumulasi kepentingan-kepentingan aktor-aktor di dalamnya. Hal ini dapat dilihat dari karakteristik gerakan Reforma Agraria kaum kiri, kaum feodal serta petani dan masyarakat miskin (kota). Semua berjuang untuk kesejahteraan agraria, semua berjuang dengan cara yang berbeda-beda dan hingga kini hasilnya dianggap belum memuaskan semua. Negara perlu mengambil peran yang lebih besar. Ketimbang mengatur pemilikan, pembagian dan pemanfaatan tanah "milik orang lain" bukan tidak mungkin negara mengatur pemilikan, pembagian dan pemanfaatan tanah "miliknya sendiri."Sudah saatnya aset-aset perkebunan negara dibuka secara luas dan transparan untuk dikelola publik, sebagai langkah masuk menuju Reforma Agraria yang mensejahterakan semua.
\end{abstract}

\section{Kata Kunci: Perencanaan, Gerakan Sosial, Reforma Agraria}

Abstract; Agrarian Reform has become an issue of social movements in Indonesia. In practice, the characteristics of the growing movement to fight for Agraria Reform have diverse variants. This differentiation is influenced by the preferences of the movement actors in interpreting Agraria Reform for the sake of their struggle. Inevitably, the Agrarian Reform movement - like the typology of other movement issues - is the accumulation of the interests of the actors within it. This can be seen from the characteristics of the Agraria Reform movement of the left, the feudal lords and peasants and the poor (city). All fought for agrarian welfare, all fought in different ways and until now the results were deemed unsatisfactory to all. The state needs to take a greater role. Rather than regulating the ownership, distribution and use of land "owned by others" it is not impossible for the state to regulate the ownership, distribution and use of land "owned by itself." It is time for state plantation assets to be widely opened and transparent for public management, as a step towards agrarian reform that makes all prosperous.

Keywords: Planning, Social Movement, Agrarian Reform 


\section{Pendahuluan}

"Awalnya saya kira perjuangan saya hanya untuk menyelamatkan pohon karet. Kemudian saya mengira saya berjuang untuk menyelamatkan hutan hujan Amazon.

Kini, saya sadar saya berjuang bagi kemanusiaan (Chiko Mendes, 1988).

Dewasa ini, perhatian terhadap konservasi lingkungan hidup menjadi salah satu retorika tersendiri dalam kategorisasi negara yang dianggap maju dan beradab-di samping demokratisasi, serta tentu saja penegakan hukum dan HAM. Dalam tujuh skenario penyelesaian utang luar negeri Indonesia yang direkomendasikan INFID (International NGO Forum on Indonesian Development), sebuah forum NGO antarornop Indonesia-Belanda misalnya, selain skenarioskenario membayar utang penuh; menggolongkan Indonesia sebagai negara miskin yang berhak memperoleh keringanan pembayaran utang atau disebut juga HIPC (Highly Indebted Door Country), atau penjadwalan utang; terdapat juga skenario pengalihan utang (debt swap) yang dapat dimaknai sebagai pengalihan kewajiban pembayaran utang secara tunai dengan konsesi untuk memperbaiki kondisi lingkungan (debt for nature swap) secara khusus dengan menawarkan komitmen pemerintah untuk menutup sejumlah Hak Penguasaan Hutan (HPH) yang bermasalah. (Zahra, 2003). Ini menandakan persolan lingkungan hidup telah menjadi isu global yang tidak hanya menyangkut batas-batas geografis suatu wilayah. Bahkan isu lingkungan telah menjadi salah satu alternatif penyelesaian utang suatu negara-sesuatu yang tak terbayangkan selama ini.
Pada praktiknya, persoalan lingkungan bertemali dengan isu Reforma Agraria. Istilah Reforma Agraria di Indonesia pertama kali diintroduksi oleh Tjondronegoro dan Wiradi sejak tahun 1984 dalam buku Dua Abad Penguasaan Tanah. Istilah Reforma Agraria diturunkan dari Bahasa Inggris yang bersumber dari Bahasa Spanyol, Agrarian Reform. Istilah Reforma Agraria (Agrarian Reform) seringkali bersinggungan dan kemudian disalahpahami sebagai landreform. landreform secara sederhana diterjemahkan sebagai penataan ulang struktur agraria (Wiradi, 2004). Landreform in practice seringkali disederhanakan sebagai redistribusi lahan. Lahan menjadi isu utama karena landreform dilakukan dengan mengandaikan telah terjadi ketimpangan kepemilikan, penguasaan, pemanfaatan dan pengelolaan atas tanah. Selain istilah Reforma Agraria, sejumlah kalangan juga mengenalkan istilah Pembaruan Agraria sebagai terjemah dari Agrarian Reform (Kompas, 22 Februari 2011).

Landreform adalah ruh Reforma Agraria dalam pengertian redistribusi pemilikan dan penguasaan tanah. Meskipun demikian landreform tidak akan berhasil jika tidak didukung oleh program-program penunjang seperti pengairan, perkreditan, penyuluhan, pendidikan, pemasaran, dan sebagainya, yang secara holistik aspek-aspek di luar redistribusi lahan ini disebut Reforma Agraria (Tjondronegoro \& Wiradi, 1984).

Landreform telah berlangsung sejak peradaban agraris lahir di tengah masyarakat. Dalam Kronik China kuno disebutkan bila penataan struktur (kepemilikan) atas tanah ditata dengan redistribusi setiap 3 tahun sekali (Russell King 1977, Prosterman 1990, 
dalam Wiradi, 2004). Kitab Perjanjian Lama karya Leviticus juga menyebut adanya Tahun Jubilee yang jatuh setiap 50 tahun sekali. Pada Tahun Jubilee dilakukan redistribusi lahan. Redistribusi lahan dilakukan karena dianggap terjadi ketimpangan penguasaan lahan yang berakibat pada ketimpangan sosial ekonomi dan budaya dalam masyarakat.

Dalam perkembangannya, istilah landreform dianggap kurang mengakomodasi semangat zaman, terutama isu yang hanya terfokus pada redistribusi lahan. Persoalan pertanahan dianggap tak sesederhana redistribusi lahan tetapi juga mencakup aspek-aspek kehidupan masyarakat yang bertumpu pada sektor agraria. Di kalangan akademik kemudian dikenalkan istilah Agricultural Development. Namun istilah Agricultural Development dianggap kurang seluas istilah agraria, sehingga istilah Agrarian Reform yang diindonesiakan menjadi Reforma Agraria lebih banyak digunakan.

Istilah Reforma Agraria sendiri ditafsirkan dalam banyak definisi. Dalam Piagam Petani (The Peasant's Charter) (TPC, 1981:6 dalam Wiradi, 2004). Disebutkan bahwa Tujuan Reforma Agraria dan Pembangunan Pedesaan adalah transformasi kehidupan dan kegiatan pedesaan dalam semua aspeknya: ekonomi, sosial, budaya, kelembagaan, lingkungan, dan kemanusiaan. The Peasant's Charter memandang bahwa usaha mula-mula mewujudkan Reforma Agraria adalah menghapus kemiskinan untuk mewujudkan pertumbuhan dengan pemerataan melalui redistribusi kuasa ekonomi dan politik serta partisipasi publik di bidang agraria. Dari sini kita dapat menyimpulkan bahwa Land Reform merupakan bagian integral dari strategi Reforma Agraria.

Perspektif lain mengenai definisi Reforma Agraria dapat dibaca dari Deklarasi Pembaruan Agraria (Bachriadi, 2007). Deklarasi Pembaruan Agraria menyebut bahwa Pembaruan Agraria merupakan penataan kembali penguasaan, penggunaan, pemanfaatan, peruntukan dan pemeliharaan sumber-sumber agraria sebagai pra-kondisi dari pembangunan. Pembaruan agraria dipercayai pula sebagai proses perombakan dan pembangunan kembali struktur sosial masyarakat, khususnya masyarakat pedesaan, sehingga tercipta dasar pertanian yang sehat, terjaminnya kepastian penguasaan atas tanah bagi rakyat sebagai sumberdaya kehidupan mereka, system kesejahteraan sosial dan jaminan sosial bagi rakyat pedesaan, serta penggunaan sumberdaya alam sebesarbesarnya untuk kemakmuran rakyat (Bachriadi, 2007).

Kedudukan agraria, dan dengan demikian sekaligus kedudukan Reforma Agraria dianggap penting sebagai modal dasar pembangunan suatu negara. Bila sebelumnya kita mengenal dikotomi modal dasar pembangunan ekonomi atau politik, hari-hari belakangan kita disuguhi alternatif modal dasar pembangunan, yaitu reforma agraria (teologis.wordpress.com, 2011). Hal ini bukan tidak beralasan dan sekedar sofistikasi, karena karakteristik banyak negara adalah agraris. Dengan demikian, pembangunan harus didasarkan pada penataan struktur agrarianya terlebih dahulu. Aspek agraria bertemali dengan aspek ekonomi dan politik, sehingga bila aspek agraria telah tertata, maka aspek ekonomi dan politik sekaligus akan tertata. 
Dalam perkembangannya Reforma Agraria di Indonesia tidak berada dalam ruang sosial-hampa. Periode-periode perkembangan Reforma Agraria ditandai dengan munculnya isu-isu agraria yang diangkat dan lahirnya kelompok-kelompok pejuang Reforma Agraria. Masing-masing isu dan kelompok diperjuangkan sesuai konteks, persepsi dan semangat zaman. Akibatnya perjuangan Reforma Agraria menjadi perjuangan yang simultan, berkelanjutan dan tak berkesudahan sepanjang kehidupan manuisa masih menjejak bumi-yang dibentuk oleh unsur kimia bernama tanah. Berdasarkan pada uraian diatas, maksud tulisan ini adalah memberi kajian pada karakteristik Perencanaan Pembangunan dan Gerakan Sosial dalam Reforma Agraria di Indonesia.

\section{Metode Penelitian}

Penelitian ini merupakan penelitian kualitatif dengan menggunakan metode studi kepustakaan. Menurut Miles dan Huberman penelitian kualitatif merupakan penelitian yang mendeskripsikan penjelasan, alur peristiwa secara kronologis, dan sebab akibat dari obyek yang diteliti (Miles dan Huberman, 1992). Sementara studi kepustakaan merupakan penelitian dengan menggunakan data sekunder yang dapat diperoleh dari literatur, arsip media massa maupun dokumen-dokumen (Moleong, 2002).

\section{Pembahasan}

\section{a. Reforma Agraria sebagai Metode Perjuangan Kaum Kiri}

Di Indonesia perjuangan mewujudkan tatanan ideal sebagaimana tujuan Reforma Agraria telah berlangsung sejak zaman kolonial ditandai dengan penerbitan UU
Agraria tahun 1870. Pada masa kemerdekaan, telah diterbitkan UU No. 5 Tahun 1960 Tentang Peraturan Dasar Pokok-Pokok Agraria dan UU No. 2 Tahun 1960 tentang Perjanjian Bagi Hasil Pertanian. Kedua UU ini telah menjadi tema diskusi yang menarik terutama bila dikaitkan sebagai isu gerakan bagi kelompok-kelompok kiri, sebut saja Partai Komunis Indonesia (PKI). Dalam jangka waktu yang lama isu Land Reform-amanat yang ditafsirkan dari UU Pokok Agrariatelah lekat dan identik dengan perjuangan komunisme dan Partai Komunis Indonesia (PKI).

Banyak sebab "kegagalan" Reforma Agraria pada tahun 1960-an. Dari sisi sistem, UU Pokok Agraria baru saja diundangkan (tahun 1960). Wajar, bila masih banyak terdapat mispersepsi di kalangan publik, terutama bagaimana Reforma Agraria dilaksanakan. Tahun-tahun setelahnya menjadi tahun-tahun yang panas, karena Reforma Agraria disederhakan menjadi penyerobotan tanah milik "tuan tanah". Ketentuan undang-undang kurang memahami karakteristik sosial masyarakat dalam mengkategorikan "tuan tanah" ini. "Tuan tanah" merupakan bahasa massa untuk penyebut pemilik tanah di atas plafon (ceiling) kepemilikan tanah. UUPA mengatur plafon bawah kepemilikan tanah adalah 2 hektare sementara plafon atas pemilikan tanah diatur secara berjenjang sesuai jenis penghitungan tanah dan kepadatan agraris (Shohibuddin, 2012). Kategori petani pemilik tanah minimal 2 hektare sebagai batas bawah cenderung ambisius untuk ukuran Jawa, termasuk kondisi di Jawa pada tahun 1960-an sekalipun. Pada masa itu rata-rata kepemilikan petani hanya 0,5 Hektare, atau biasa disebut petani gurem. Ketentuan batas 
bawah minimal 2 Hektare membuat sebagian (besar) petani dapat memiliki "hak" atas kepemilikan tanah minimal. Celakanya lagi, mereka yang disebut "tuan-tuan tanah" ratarata memiliki tanah tidak lebih dari 10 Hektare, jumlah yang dianggap "masih wajar" dalam konteks Jawa saat itu.

Secara praktik, gerakan penyerobotan yang dilakukan massa tani tidak melulu soal "agraria" tetapi dengan segera bergeser menjadi agitasi "politik (Sulistiyo, 2000)." Apa yang disebut sebagai Reforma Agraria sekaligus menjadi janji kampanye kelompokkelompok politik yang berafiliasi dengan Partai Komunis Indonesia. Semangat untuk menyejahterakan petani bersimbiosis dengan kecenderungan perkaderan partai dan suplai suara partai. Pada posisi ini, perjuangan sudah menjadi tidak murni lagi. Di sisi lain, mereka yang disebut sebagai "tuan tanah" "kebetulan" adalah anggota atau simpatisan Nahdlatul Ulama (NU) sebagai partai maupun ormas dan Partai Nasional Indonesia (PNI), partainya birokrat kala itu yang diidentifikasi sebagai kapbir oleh PKI. Baik NU maupun PNI juga sama-sama hendak merebut simpati petani sekaligus memiliki riwayat rivalitas yang panjang sejak lama dengan PKI. Perseteruan lagi-lagi menjadi tidak murni agraria lagi. Dan kesudahannya pun dapat ditebak, publik kemudian "alergi" dengan isu Reforma Agraria.

\section{b. Reforma Agraria sebagai Perjuangan Kaum Feodal}

Persoalan agraria tak hanya lahir pada periode panas dekade pertama 1960 dengan antiklimaks pada tahun 1965. Hingga hari ini persoalan agraria masih aktual dan membutuhkan kejernihan epistemologis untuk mengurainya. Negara tak lagi "malu- malu" menyebut idiom Reforma Agraria, ditandai dengan lahirnya PP No. 11 Tahun 2010 tentang Penertiban dan Pendayagunaan Tanah Terlantar sebagai salah satu terjemah UU Pokok Agraria 1960 yang belum pernah direvisi dan dicabut. PP No.11 Tahun 2010 ini merupakan amandemen PP No. 36 Tahun 1998 yang dianggap belum mampu menyelesaikan salah satu persoalan agraria di tanah air. PP No. 11 Tahun 2010 diderivasikan dalam Peraturan Kepala BPN No. 4 Tahun 2010 tentang Tata Cara Penertiban Tanah Terlantar (KPA, 2010).

Jauh sebelum terbit PP yang sejalan dengan perspektif Reforma Agraria, Susilo Bambang Yudhoyono dan Muhammad Jusuf Kalla ketika menjadi Calon Presiden dan Calon Wakil Presiden pada Pemilu 2004 menerbitkan buku yang memuat visi dan misinya sebagai presiden dan wakil presiden yang akhirnya terpilih pada tahun 2004. Dalam buku visi dan misi SBY-MJK ini, pada agenda dan program ekonomi dan kesejahteraan nomenklatur Reforma Agraria secara eksplisit disebut dua kali. Kebijakan di bidang ekonomi dan kesejahteraan rakyat ini antara lain memuat kebijakan a) Perbaikan dan penciptaan kesempatan kerja, (b) Peningkatan kinerja dan stabilitas ekonomi makro, (c) Penghapusan kemiskinan, (d) Peningkatan akses rakyat terhadap pendidikan yang lebih berkualitas, (e) Peningkatan akses rakyat terhadap layanan kesehatan yang lebih berkualitas, (f) Penghapusan ketimpangan dalam berbagai bentuknya, (g) Perbaikan pengelolaan sumber daya alam serta pelestarian mutu lingkungan hidup, dan (h) Revitalisasi pertanian dan aktivitas pedesaan. Pada agenda ini, pelaksanaan reforma agraria disebutkan sebanyak dua kali, yakni pada agenda (a) dan 
(h) (Bachriadi, 2007). Visi dan misi SBY-MJK ini dianggap sebagian kalangan sebagai salah satu langkah maju dalam penerapan Reforma Agraria di Indonesia, meskipun baru sebatas wacana. Baru pada tahun 2010, Pemerintahan SBY-(kali ini dengan) Boediono menerbitkan PP mengenai Penertiban dan Pendayagunaan Tanah Terlantar Milik Negara.

Konflik keagrarian di tanah air umumnya terjadi karena sengketa kepemilikan dan pemanfaatan tanah. Tanah ulayat merupakan jenis tanah yang paling sering disengketakan. Tanah ulayat menjadi akar sengketa terutama karena kejelasan kepemilikan. Masyarakat adat umumnya mendasarkan kepemilikan secara sosiologis berdasarkan norma yang berlaku dalam masyarakatnya. Sementara negara dan kuasa modal umumnya mendasarkan kepemilikan tanah-yang dianggap tanah ulayatberdasarkan bukti tertulis yang dimiliki. Apalagi negara seringkali mendasarkan pada prinsip, yakni bila bidang tanah tidak dapat dibuktikan kepemilikannya dianggap sebagai tanah negara.

Masyarakat mendasarkan kepemilikan dan penguasaan atas tanah berdasarkan norma yang secara generik umumnya mengatur soal tidak ada pihak lain yang sebelumnya telah menempati tanah tersebut; tanah tersebut dikuasai semata-mata untuk memenuhi kebutuhan hidupnya; prosesnya menjadi penghuni pertama telah memenuhi norma sosial yang berlaku di masyarakat setempat; serta kepenghuniannya mendapat pengakuan dari masyarakat setempat (Nugroho, 2012).

Namun kita perlu hati-hati mendudukkan konflik agraria atas hak ulayat dan bagaimana kelompok adat seharusnya diidentifikasi. Untuk mengurai konflik adat atas isu agraria ini perlu ditelisik sejarah pemilikan tanah di tanah air, terutama di Jawa (Poesponegoro dan Notosusanto, 1990). Pada mulanya, semua tanah adalah milik raja (dalem). Dalam melaksanakan pemerintahan raja dibantu oleh keluarga (sentana dalem) dan pegawai (abdi dalem). Atas bantuan dan kinerja keluarga dan pegawainya, raja memberi upah tidak dalam bentuk gaji melainkan hak atas tanah (lungguh). Lungguh dibagikan kepada keluarga dan pegawai berdasarkan kedudukannya. Untuk memastikan tidak terjadi pemberontakan, keluarga dan abdi umumnya diharuskan tinggal di ibukota kerajaan. Sebagai wakil keluarga dan abdi yang mengelola tanah lungguh diangkat bekel di masing-masing lungguh. Bekel diberi upah 0,20 (seperlima) hasil pertanian dalam satu lungguh. Upah 0,20 ini kemudian dimaterialkan menjadi hak atas sebagian tanah lungguh untuk bekel yang kemudian disebut sebagai tanah bengkok. Rakyat yang hidup di atas tanah lungguh dianggap menumpang-atas kebaikan raja dan bangsawan-dan disebut magersari. Warga desa yang menjadi magersari disebut sikep. Mereka "menyewa" tanah raja dan bangsawan dengan memberi bagi hasil (upeti) dari hasil panennya kepada bangsawan pemilik lungguh. Upeti tersebut berupa hasil produksi maupun "upeti” berupa tenaga kerja.

Raja memperoleh pemasukan dari pajak, diantaranya pajak (upeti) yang dikirim lungguh-lungguh. Dalam kasus-kasus tertentu, karena kemurahan hati raja daerah-daerah tertentu dibebaskan dari pajak secara permanen maupun temporer. Tanah bebas pajak permanen disebut perdikan (tanah merdeka dari pajak namun tetap berada di bawah daulat raja secara politik). Tanahtanah perdikan ini umumnya berstatus "desa" 
meskipun terdapat juga yang wilayahnya seluas "kabupaten"-dan kemudian memerdekkan diri (misalnya Yogyakarta ketika memerdekakan diri dari Pajang). Selain itu terdapat tanah-tanah bebas pajak temporer, misalnya sekian tahun. Pembebasan pajak ini misalnya karena wilayah-wilayah tersebut membantu raja dalam memadamkan pemberontakan. Wilayah-wilayah lungguh di kawasan Tegal, Banyumas dan Pekalongan pernah dibebaskan dari pajak selama 2 tahun karena membantu raja memadamkan "pemberontakan" Pangeran Diponegoro.

Sejak awal, tanah-tanah di Jawa adalah milik raja u.b. bangsawan. Sejak mula sistem agraria Jawa tidak mengenal hak milik pribadi rakyat. Meskipun rakyat telah tinggal di suatu wilayah jauh sebelum kerajaan terbentuk, sesaat setelah wilayahnya dinyatakan berada dalam yurisdiksi suatu kerajaan maka saat itu pula ia berstatus magersari. Dalam sejarahnya banyak petani yang masuk hutan, membuka perkampungan dan lahan pertanian (babat alas). Namun karena prinsip pemilik tanah adalah raja, maka usaha petani membuka lahan pertanian bukan dianggap sebagai kepemilikan pribadi melainkan "membantu" raja dalam membuka wilayah baru. Sejarah perkembangan kepemilikan aset pada banyak kebudayaan umumnya mendasarkan pada "hukum agraria" purba ini: semua tanah milik raja. Isu hak milik pribadi baru lahir dari rahim revolusi Perancis, ketiak kelas menengah (pedagang dan tukang) naik daun dan menjadi penguasa baru sejajar dengan penguasa lama (raja dan bangsawan).

Dalam perkembangannya, bangsawanbangsawan pemilik lungguh menyewakan tanahnya kepada perkebunan-perkebunan besar. Perkebunan-perkebunan besar membayar sewa kepada bangsawan, dan bangsawan membayar upeti kepada raja. Baik kekuasaan raja maupun kekuasaan bangsawan semakin melemah saat aneksasi kolonial. Raja yang ditaklukan mendapat gaji dari gubermen. Sebagian wilayah dianeksasi dan bangsawan yang ada (level bupati ke bawah) menjadi bawahan gubermen. Sebagian tanah diambil alih langsung oleh negara dan disewakan kepada perkebunan besar, di samping sebagian kecil tanah-tanah yang masih disewakan bangsawan kepada perkebunan-perkebunan. Pada masa kemerdekaan perkebunan-perkebunan yang ada sebagian diantara dinasionalisasi menjadi milik negara, dalam hal ini Republik Indonesia.

Hari-hari belakangan, rakyat mulai melirik tanah-tanah perkebunan maupun tanah-tanah hutan negara sebagai tanah ulayat yang itu artinya "tanah rakyat." Perlu diidentifikasi siapa yang disebut "rakyat" ini. Petani kawula atau kraton/golongan adat (raja, bangsawan dan keturunannya). Kraton dan kelompok-kelompok adat di waktu-waktu belakangan ini kerap menggelar kongres yang antara lain hendak memulihkan hak-hak ekonomi kraton/kelompok adat-setelah mimpi mengembalikan hak politik cenderung berpeluang tipis untuk berhasil. Hak-hak ekonomi ini dengan sederhana maknanya diartikan sebagai penguasaan atas tanah "ulayat" atau tanah "eks kraton/kerajaan." Melihat sejarah panjang penguasaan agraria di tanah air, menjadi jelas bahwa perjuangan "kaum adat" ini lebih banyak dikategorikan sebagai perjuangan neo-feodal ketimbang perjuangan petani. 


\section{c. Reforma Agraria sebagai Perjuangan Petani dan Kaum Miskin (Kota)}

Republik Indonesia sejak lama telah memiliki lembaga yang memiliki tugas dan kewenangan di bidang agraria. Saat ini Badan Pertanahan Nasional (BPN) sebagai Lembaga Pemerintah Non-Departemen (LPND), dianggap sebagai leading sector pembangunan pertanahan nasional. BPN telah mencanangkan "Empat Prinsip Pertanahan" yang memuat:

1. Pertanahan harus berkontribusi secara nyata untuk meningkatkan kesejahteraan rakyat, dan melahirkan sumber-sumber baru kemakmuran rakyat;

2. Pertanahan harus berkontribusi secara nyata untuk meningkatkan tatanan kehidupan bersama yang lebih berkeadilan dalam kaitannya dengan pemanfaatan, penggunaan, penguasaan, dan pemilikan tanah;

3. Pertanahan harus berkontribusi secara nyata dalam menjamin keberlanjutan sistem kemasyarakatan, kebangsaan, dan kenegaraan Indonesia dengan memberikan akses seluas-luasnya pada generasi akan datang pada sumber-sumber ekonomi masyarakat, terutama tanah

4. Pertanahan harus berkontribusi secara nyata dalam menciptakan tatanan kehidupan bersama secara harmonis dengan mengatasi berbagai sengketa dan konflik pertanahan di seluruh tanah air, dan menata sistem pengelolaan yang tidak lagi melahirkan sengketa dan konflik di kemudian hari (Nugroho, 2012).
Kondisi eksisting hari ini mengindikasikan bahwa persoalan utama Reforma Agraria memang masih soal redistribusi lahan-yang sering disederhanakan menjadi Land Reform - serta pemanfaatan tanah terlantar-terutama milik negara. Pemanfaatan tanah terlantar milik negara dalam banyak kasus menjadi persoalan paling banyak terjadi dalam Reforma Agraria di Indonesia.

Secara sosiologis, pemanfataan atas tanah dibedakan menjadi tiga bentuk, yakni land use (peruntukan tanah), land division (pembagian tanah), dan land tenure (pemanfaatan tanah) (Tjondronegoro dan Wiradi, 2008). Aspek tenurial dari agrarian merupakan aspek yang paling dilematis di tanah air. Sejumlah lahan, baik milik negara maupun swasta yang tak produktif dimanfaatkan oleh pihak lain, terutama kelompok masyarakat miskin. Persoalan umumnya baru terjadi ketika pemilik lahan hendak memanfaatkan lahan yang telah puluhan tahun dimanfaatkan pihak lain.

$$
\text { Baik Reforma Agraria-atau }
$$

Pembaruan Agraria-sebagai terjemah Agricultural Development dan Agrarian Reform maupun landreform hadir karena terjadi konflik agraria di tengah masyarakat. Konflik agraria ini bukan tak diketahui dan direspons oleh negara. Negara telah mengeluarkan regulasi yang kemudian dikenal sebagai UU Pokok Agraria dan UU Bagi Hasil. Tahun 2003 Kepala Badan Pertanahan Nasional (BPN) misalnya menerbitkan Surat Keputusan No. 34 Tahun 2003 tentang Kebijakan Nasional di Bidang Pertanahan. SK ini telah mengidentifikasi secara garis besar terdapat beberapa tipologi sengketa tanah, yakni masalah penguasaan dan pemilikan tanah, penetapan hak dan 
pendaftaran tanah, batas atau letak bidang tanah, ganti rugi eks tanah partikelir, tanah ulayat, tanah obyek land reform, atau pembagian tanah kepada petani tak bertanah alias petani gurem dan pelaksanaan putusan pengadilan (Kompas, 11 Februari 2011).

Selain soal (bukti) kepemilikan atas tanah, tak dapat dihindarkan telah terjadi kondisi yang disebut "gerakan lapar tanah". "Gerakan lapar tanah" merupakan aksi-aksi pendudukan tanah yang tidak dimanfaatkan oleh pemiliknya dalam waktu yang lama. Tanah-tanah bekas perkebunan, termasuk tanah-tanah yang dikategorikan sebagai hutan lindung maupun Taman Nasional merupakan tanah-tanah yang sering diduduki paksa oleh warga. Alasan-alasan ekonomi dan pemenuhan kebutuhan subsistensi dasar menjadi pangkal "gerakan lapar tanah ini".

Menurut Nugroho (2012), "gerakan lapar tanah" ini disebabkan oleh karena Pertama, fungsi tanah, kandungan hasil bumi, ragam tanaman, dan hasil di atas tanah akan dieksploitasi secara masif. Kedua, penguasaan, pemilikan, penggunaan, dan pemanfaatan tanah terkonsentrasi pada pihak-pihak tertentu yang berakibat meningkatnya jumlah petani tuna wisma. Ketiga, penerbitan HGU (Hak Guna Usaha), serta pelaksanaan PIR (Perkebunan Inti Rakyat) dan TRI (Tebu Rakyat Intensifikasi). Keempat, pengambilalihan tanah masyarakat untuk keperluan kawasan industri, pariwisata, real estate, pergudangan, dan pembangunan fasilitas umum. Kelima, pencabutan hak rakyat atas tanah untuk keperluan penetapan taman nasional, hutan lindung dan sebagainya yang mengatasnamakan kelestarian lingkungan.

“Gerakan lapar tanah" juga menggejala di kota-kota besar. Pelakunya adalah masyarakat miskin kota yang tidak memiliki akses dan sumber daya untuk memiliki tanah di kota-kota besar yang tentu saja harganya mahal. Obyek penyerobotan tidak hanya tanah-tanah terlantar, tetapi juga tanah-tanah yang dilindungi seperti bantaran sungai, kolong jembatan penyeberangan, tanah milik PT KAI maupun daerah milik jalan (damija). Pada banyak kasus, karakteristik "gerakan lapar tanah" di kawasan perkotaan ini digunakan untuk hunian warga miskin. Namun mengidentifikasi "warga miskin" dalam konteks ini pun perlu hati-hati. Tidak sedikit permukiman yang terbentuk dari lahan serobotan ini cukup layak untuk dikatakan miskin. Menurut perspektif tata ruang karakteristik kawasan yang ada lebih tepat dikategorikan sebagai kawasan padat hunian dan padat penduduk (squater) ketimbang kawasan kumuh (slum).

\section{Kesimpulan}

Secara sederhana, pangkal konflik agraria dapat disarikan dari 2 sebab, yaitu perbedaan konsep dan kepentingan dalam memaknai pemilikan, pembagian dan pemanfatan tanah (Scot, 1976 dalam Ahmadin 2007). Pemerintah sebagai regulator menetapkan kebijakan dan struktur serta pola ruang dalam rencana tata ruang. Pemerintah juga mengatur kepemilikan dan pembagian tanah dalam sejumlah peraturan keagrariaan. Secara idiil, negara kita bukan negara etatis sehingga masih memberi ruang bagi kepemilikan properti individu. Masalah terjadi manakala negara mengatur pemilikan, pembagian dan pemanfaatan tanah individu, sementara individu merasa sebagai pemilik sah atas tanah yang diatur oleh undangundang. Penetapan pola ruang (peruntukan lahan misalnya), merupakan diskusi menarik 
namun tak berkesudahan. Negara dituntut mengatur peruntukan ruang, sementara ruang yang diatur tidak seluruhnya milik negara-sebagian besar milik privat. Celakanya, negara tidak (atau belum?) mampu memberikan kompensasi terhadap individu yang tanahnya diatur peruntukannya dalam tata ruang-yang tidak sesuai dengan rencana pengembangan tanah oleh individu tersebut.

Dalam konteks pemilikan, pembagian dan pemanfaatan tanah, pemerintah seringkali mengatur terhadap tanah-tanah yang (setidaknya pernah) dikuasai individu. Pengaturan-pengaturan terhadap tanah bermilik namun oleh regulasi dianggap tidak layak memiliki rawan konflik, utamanya gugatan hukum. Langkah paling praktis yang mungkin dilakukan adalah melakukan pengaturan terhadap pemilikan, pembagian dan pemanfaatan tanah yang sudah "jelasjelas" milik negara. Perkebunan-perkebunan yang berhimpun dalam BUMN misalnya, merupakan potensi pelaksanaan Reforma Agraria yang lebih praktis. Dari sisi kepemilikan, negara relatif tidak menemui kendala kecuali niat baik (good will). Tinggal kemudian diatur pemanfaatannya.

Pemanfaatan tanah-tanah perkebunan negara dengan model Lembaga Masyarakat Desa Hutan (LMDH) masih sering disebut sebagai Reforma Agraria semu. Masyarakat masih dianggap "pengganggu" dan untuk itu perlu disuap dengan "uang recehan." Pemanfatan yang dilakukan warga LMDH pun masih terbatas pada usaha-usaha sinterklasi dan "CSR." Sudah saatnya masyarakat memperoleh ruang yang lebih luas untuk mempengaruhi kebijakan dan jalannya perkebunan milik negara sebagai modal dasar Reforma Agraria di Indonesia. Bentuk sederhananya, masyarakat dijadikan "pemilik" perkebunan-perkebunan yang ada yang turut terlibat aktif dalam pengelolaan perkebunan. Untuk itu yang diperlukan hanya dua, kemauan dan keihklasan semua pihak di sektor keagrariaan.

\section{Daftar Pustaka}

Ahmadin. 2007. Masalah Agraria di Indoensia Masa Kolonial. Jurnal Attoriolong Vol. IV No. 1 Januari-Juni 2007. Dikutip dari http://ahmadin-

umar.blogspot.co.id/2012/06/masalahagraria-di-indonesia-masa.html

Bachriadi, Dianto dan Noer Fauzi, 2001. Dari Aksi-aksi Protes menuju Pembaruan Agraria di Indonesia Masa Kini, makalah yang disampaikan dalam Lokakarya "Reconstructing the Historical Tradition of 21th Century Indonesian Labour", CLARA-CAPTRANS-LIPI, Bali 4-6 Desember 2001;

Bachriadi, Dianto, 2001. Melihat Selayang ke Dalam: Latar Belakang Munculnya Usulan Ketetapan MPR tentang Pembaruan Agraria dan Pengelolaan Sumberdaya Alam yang Berkelanjutan, pengantar editor dalam Meneguhkan Komitmen, Mendorong Perubahan, Dianto Bachriadi (ed.), hal. v-xxxiv (Bandung: KPA-Pokja PSDA-KSPA).

Bachriadi. Dianto, 2007. Reforma Agraria untuk Indonesia: Pandangan Kritis tentang Program Pembaruan Agraria Nasional (PPAN) atau Redistribusi Tanah ala Pemerintahan SBY, Makalah dalam Pertemuan Organisasi-organisasi Rakyat se-Jawa di Magelang, 6-7 Juni 2007.

BPN RI. 2015. Sekilas Reforma Agraria. Dikutip

dari 
http://www.bpn.go.id/Program/Reform a-Agraria.

Johnson, Doyle Paul. 1986. Teori Klasik dan Modern. Terjemahan Robert MZ Lawang. PT Gramedia: Jakarta.

Laporan Komisi Agraria SBD, 2004. Catatan Ringkas Meninjau Ulang Konsep Reforma Agraria. SBD: Yogyakarta.

Marwati Poesponegoro \& Nugroho Notosusanto. 1990. Sejarah Nasional Indonesia Jilid II. Jakarta: Balai Pustaka

Miles, Matthew B dan A. Michael Huberman. 1992. Analisis Data Kualitatif: Buku Sumber tentang Metode-Metode Baru. Diterjemahkan oleh Tjejep Rohendi Rohidi. UI Press. Jakarta.

Moleong, Lexy J. 2002. Metodologi Penelitian Kualitatif. Cetakan keenambelas. PT. Remaja Rosdakarya. Bandung.

Nugroho, Aristiono, 2012. Kepastian dan Keadilan Tenurial. Dikutip dari http://sosiologipertanahan.blogspot.co.i d/2012/01/kepastian-dan-keadilantenurial.html

Nugroho, Aristiono, 2012. Kepercayaan Masyarakat dan Empat Prinsip Pertanahan. Dikutip dari http://sosiologipertanahan.blogspot.co.i d/2012/02/kepercayaan-masyarakatdan-empat.html

Rieskiyanto, Angga. 2012. Reforma Agraria: Ruang Baru Politik dan Kebijakan Pertanahan. Dikutip dari https://teleologis.wordpress.com/2011 /12/20/reforma-agraria-ruang-barupolitik-dan-kebijakan-pertanahan/

Shohibudiin. 2012. Sketsa Perkembangan Reforma Agraria dan Studi Agraria. Dikutip dari http://indoprogress.com/2012/02/sket sa-perkembangan-reforma-agraria-danstudi-agraria/

Sulistyo, Hermawan. 2000. Palu Arit di Ladang Tebu: Sejarah Pembantaian Massal yang Terlupakan (1965-1966). KPG: Jakarta.

Tjondronegoro, M.P dan Gunawan Wiradi, 2008. Dua Abad Penguasaan Tanah. Yayasan Obor Indonesia: Jakarta.

Zahra, Ning, et. al., 2003. Siapa Berutang Siapa Membayar? INFID: Jakarta. 